\title{
KINERJA USAHA TANAMAN HIAS POTONG PT PESONA DAUN MAS ASRI
}

\author{
Muhamad Arief Bangun Sanjaya*)1, Heny K Daryanto ${ }^{* *}$, dan Netti Tinaprilla***) \\ *) Sekolah Bisnis, Institut Pertanian Bogor \\ Jl. Raya Pajajaran, Bogor - Indonesia 16151 \\ **) Departemen Ilmu Ekonomi, Fakultas Ekonomi Dan Manajemen, Institut Pertanian Bogor \\ Gedung FEM Lt. 2 Jl. Kamper, Kampus IPB Dramaga Bogor 16680
}

\begin{abstract}
Pesona Daun Mas Asri is a company in cut flowers and leaves cultivation. The achievement is shown by the performance of the company. The overall company's performance contributes in developing the company's vision. Balanced score card is a management tool used to observe and maintain the stability between financial indicators (financial perspective) and non financial indicators (customer, business internal process, growth and learning). The objective of the journal is to plan the performance of the company using balanced scorecard approach, analyze and calculate the vision, mission and strategy implemented by Pesona Daun Mas in it business activity. The result for every strategic target shows that the performance of Pesona Daun Mas is excellent with the achieved score of 78,04\%. However the target for the selling growth level and marketing activities are classified as average which means that it still needs to be developed.
\end{abstract}

Keywords: balanced scorecard, performance evaluation, KPI performance index, ornamental plants cut

\begin{abstract}
ABSTRAK
Pesona Daun Mas Asri merupakan perusahaan yang bergerak dalam bidang budi daya bunga potong dan daun potong. Pencapaian dalam menjalankan sebuah perusahaan dapat dilihat dari kinerja perusahaan tersebut.Kinerja perusahaan Pesona Daun Mas Asri secara keseluruhan dapat berkontribusi untuk mengembangkan perusahaan dalam mencapai visi. Balanced scorecard adalah salah satu alat manajemen yang dapat melihat dan menjaga keseimbangan antara indikator keuangan (perspektif keuangan) dan indikator non-keuangan (pelanggan, proses bisnisinternal, pertumbuhan dan pembelajaran). Tujuan dari jurnal ini adalah untuk merancang pengukuran kinerja perusahaan dengan pendekatan Balanced scorecard. Penelitian ini juga bertujuan menganalisis dan mengukur pelaksanaan visi, misi dan strategi yang dijalankan oleh Pesona Daun Mas Asri dalam kegiatan bisnisnya. Selain itu, memberikan saran dan rekomendasi, serta merumuskan implikasi manajerial untuk Pesona Daun Mas Asri. Hasil pengukuran menunjukan kinerja dariPesona Daun Mas Asri termasuk sangat baik dengan nilai mencapai 78,04\%. Pada setiap sasaran strategis mencapai kinerja yang baik. Namun, target pada sasaran strategis tingkat pertumbuhan penjualan dan kegiatan pemasaran menunjukan perlu pengembangan karena sasaran strategis tersebut masuk ke dalam skala penilaian rata-rata (average).
\end{abstract}

Kata kunci: balanced scorecard, evaluasi kinerja, indeks kinerja, KPI, tanaman hias potong

${ }^{1}$ Alamat Korespondensi:

Email: ariefbs.01@gmail.com 


\section{PENDAHULUAN}

Salah satu kelompok dalam subsektor hortikultura yang potensial untuk dikembangkan di Indonesia adalah florikultura (tanaman hias seperti bunga potong, daun potong dan tanaman hias pot lainnya). Dari data Perkembangan PDB Riil subsektor Hortikultura disimpulkan bahwa nilai PDB untuk tanaman hias atau florikultura di Indonesia meningkat dengan laju pertumbuhan rata-rata $8,22 \%$ per tahun (Susenas, 2011). Laju pertumbuhan tersebut adalah laju pertumbuhan terbesar dalam Subsektor Hortikultura setelah tanaman obat. Melihat banyaknya faktor yang dapat meningkatkan permintaan tanaman hias seperti tingkat pendidikan yang berdampak pada meningkatnya kesadaran akan keindahan, bertambahnya populasi, banyaknya pembangunan gedung, hotel dan perumahan dengan dekorasi tanaman yang beragam dapat diperkirakan permintaan akan tanaman hias pun stabil bahkan cenderung meningkat di tahun-tahun mendatang.

Upaya peningkatan produksi hortikultura dilakukan melalui perluasan area panen dan peningkatan produktivitas. Selama tahun 2000-2010, secara keseluruhan produksikomoditashortikulturamengalami peningkatan dari 17,34 juta ton menjadi 31,18 juta ton, atau peningkatan sebesar 3,68\% per tahun (Susenas, 2011). Peningkatan terbesar terjadi pada kelompok tanaman hias dengan laju sebesar 10,16\% per tahun, menyusul kelompok tanaman obat dengan laju 5,45\% per tahun, diikuti kelompok buah sebesar $4,98 \%$ per tahun dan kelompok sayuran sebesar 1,32\% per tahun (Susenas, 2011).

Pesona Daun Mas Asri adalah salah satu perusahaan agribisnis berbadan hukum Perseroan Terbatas yang bergerak dalam bidang usaha budi daya tanaman hias potong. Produk yang dihasilkan perusahaan ini adalah daun potong dan bunga potong yang nantinya digunakan sebagai dekorasi baik untuk dekorasi ruangan gedung dan hotel-hotel mewah, dekorasi berupa rangkaian bunga dari yang kecil sampai dengan karangan ucapan dan dekorasi pada acara perkawinan dan acara-acara besar lainnya. Saat ini perusahaan mayoritas menjual produknya ke para trader tanaman hias potong baik di dalam kota maupun ke luar kota. Perusahaan berdiri sudah lebih dari 20 tahun dan namanya sangat dikenal baik dikalangan pengusaha maupun konsumen tanaman hias sampai saat ini.
Pencapaian posisi dalam menjalankan sebuah perusahaan dapat dilihat dari kinerja perusahaan tersebut. Kinerja merupakan hasil pekerjaan yang mempunyai hubungan kuat dengan tujuan strategis organisasi, kepuasan konsumen dan memberikan kontribusi pada ekonomi (Wibowo, 2007). Gibson et al. (2009) membagi kinerja dalam tiga kelompok, yaitu kinerja individu, kinerja kelompok dan kinerja organisasi. Penelitian ini berfokus pada kinerja organisasi yaitu PT Pesona Daun Mas Asri (PT PDMA). Sejak awal beropersainya PT PDMA, belum pernah malakukan evaluasi secara menyeluruh terhadap kinerja perusahaannya. Pengukuran pencapaian kinerja selama ini dilakukan hanya berdasarkan pencapaian aspek keuangan. Dengan kata lain, saat terjadi masalah dalam perusahaan, pihak manajemen masih belum mampu menemukan sumber permasalahan secara efisien. Para akademisi dan praktisi meyakini bahwa dewasa ini, hanya memperhatikan aspek finansial tidak cukup representatif menggambarkan kinerja perusahaan secara keseluruhan (Kaplan dan Norton, 1996, Ghalayini et al. 1997, Nelly dan Adam, 2000). Berdasarkan latar belakang permasalahan tersebut maka tujuan dari penelitian ini adalah menyusun rancangan pengukuran kinerja PT PDMA dengan pendekatan Balanced Scorecard (BSC); dan mengukur pencapaian kinerja PT PDMA dengan pendekatan BSC.

Berikut disajikan tinjauan penelitian terdahulu yang terkait dengan penelitian yang dilakukan. Al-Zwyalif IM (2012) dan Alsyouf I (2006) menjelaskan manfaat penerapan kerangka BSC dapat digunakan untuk mengukur dan mengidentifikasi hubungan sebab akibat dengan menggunakan strategi yang efektif dan berimplikasi pada keunggulan kompetitif perusahaan. Kemampuan BSC tersebut dapat digunakan dalam penelitian ini.

Pengukuran kinerja menggunakan metode BSC memiliki manfaat yang sangat penting pada berbagai jenis usaha maupun organisasi seperti pada penelitian Christina dan Sudana (2013) meneliti kinerja PT Adhi Karya dengan BSC, peneliti menelaah sejauh mana visi, misi dan tujuan perusahaan telah tercapai, menilai prestasi bisnis, manajer, divisi dan setiap individu dalam perusahaan serta untuk memprediksi harapan-harapan perusahaan ke depan. Jenis usaha bidang information technology (IT) pada Maula dan Ghozali (2012) menyebutkan kemajuan teknologi yang pesat mendorong persaingan yang ketat diantara para pelaku bisnis termasuk di Indonesia. Hal ini menuntut 
perusahaan meningkatkan produktivitas optimalisasi kinerja semua lini dalam menjalankan proses bisnisnya. Perencanaan harus diiringi oleh pengukuran kinerja untuk memastikan bahwa program kerja yang diambil sejalan dengan visi misi perusahaan.

Mengukur kinerja sebuah perusahaan atau organisasi menggunakan BSC dapat menunjukan perspektif mana yang berpengaruh paling besar terhadap kinerja usaha secara keseluruhan seperti pada Penelitian yang dilakukan Ardekani et al. (2013) dalam jurnal ilmiahnya menunjukkan bahwa diantara keempat perspektif BSC, aspek keuangan memiliki makna yang paling signifikan. Oleh sebab itu, rekomendasi yang dapat diberikan kepada manajer keuangan adalah memusatkan perhatian pada tiga hal, yaitu debt to asset ratio, net profit margin, dan ROA. Selain itu, pengukuran kinerja dengan metode BSC dapat dilakukan pada organisasi non profit seperti pada penelitian Penelitian Suryani et al. (2014) berjudul perancangan Balanced scorecard untuk pengembangan strategi di SEAMEO Biotrop menunjukkan bahwa pada perspektif keuangan, dana yang diterima dari pemerintah berkontribusi tertinggi terhadapkinerja, sedangkan dalam perspektifpelanggan, jumlah penelitian yang dilakukan berkontribusi tertinggi terhadap kinerja lembaga. Pada perspektif proses bisnis, MOU yang diimplementasikan memiliki kontribusi tertinggi terhadap kinerja lembaga dan pada perspektif pertumbuhan dan pembelajaran, rasio produktivitas tenaga kerja yang berkontribusi tertinggi terhadap kinerja lembaga.

Alat analisis BSC digunakan dalam penelitian Yu dan Li (2013) untuk mengukur kinerja bank. Mereka meneliti efektivitas pelaksanaan strategi industri perbankan di desa maupun kota yang merupakan titik awal penerapan prinsip dasar dari BSC. Alhyari et al. (2013) menyatakan bahwa faktor yang mendukung BSC akan berhasil dengan baik jika dilaksanakan monitoring serta pengukuran kinerja e-government di Yordania serta mengevaluasi keberhasilan dalam investasi proyek. Penelitian menunjukkan pelaksanaanan BSC dapat memaksimalkan pelayanan e-government di Yordania. Penelitian yang dilakukan Ratih et al. (2012) pada perusahaan tanaman hias menunjukanhasil matriks internal dan eksternal, posisi perusahaan pada pertumbuhan strategis sehingga perusahaan menerapkan beberapa strategi. Strategi alternatif yang dapat ditingkatkan oleh perusahaan, seperti: (1) maintaning hubungan baik dengan pelanggan dan pemasok, (2) memperluas pasar ekspor ke Asia, (3) meningkatkan jenis pohon, (4) mengikuti pameran besar, (5) berinovasi produk ke membuat trendsetter tanaman, (6) peningkatan manajemen pengetahuan untuk sumber daya manusia di perusahaan, dan (7) memaksimalkan produksi untuk pasar domestik, (8) saluran distribusi yang didirikan di setiap kota, (9) membuat target pasar yang jelas, (10) mempertahankan kualitas tanaman, (11) merestrukturisasi perusahaan dalam rangka untuk memperjelas spesialisasi pekerjaan, (12) membuat dokumen menyediakan benih sesuai dengan kebutuhan pelanggan. Strategi tersebut dapat dijadikan refrensi dalam penentuan sasaran strategis pada pengukuran kinerja pada penelitian ini karena jenis perusahaan yang sejenis, yaitu perusahaan tanaman hias.

Kita dapat mengetahui pencapaian kinerja perusahaan yang kita jalankan seperti pada penelitian Anggraini et al. (2016) yang menunjukan kinerja perusahaan tempat penelitiannya sangat baik sesuai visi, misi dan strategi perusahaan. Sistem pengukuran kinerja strategis melalui BSC bertujuan mengevaluasi kinerja dengan cara memberikan penilaian terhadap peningkatan kemampuan dipandang dari perspektif finansial dan non-finansial. Oleh karena itu, BSC digunakan untuk meninjau keputusan manajemen (Humphreys dan Trotman, 2011).

\section{METODE PENELITIAN}

Penelitian dilakukan pada perusahaan Pesona Daun Mas Asri (PT PDMA) di Ciawi, Bogor menggunakan metode pengukuran kinerja Balanced scorecard. Balanced scorecard adalah alat manajemen untuk menganalisis kinerja dengan menjaga keseimbangan antara indikator finansial (perspektif keuangan) dan non-finansial (perspektif pelanggan, proses bisnis internal, pertumbuhan dan pembelajaran) indikator kinerja jangka pendek dan jangka panjang, indikator internal dan eksternal serta indikator yang bersifat leading dan lagging. Penerapan BSC juga bertujuan mengarahkan, mengawasi dan memberikan tantangan bagi organisasi agar berhasil mencapai target yang akan dicapai di masa depan (Chavan, 2009).

Kegiatan pengumpulan data pada penelitian ini dilaksanakan selama enam bulan, sejak bulan Mei sampai dengan bulan Oktober 2015. Kinerja perusahaan yang diukur, yaitu bulan Juli 2014 sampai dengan bulan Juni 2015. Penelitian menggunakan pendekatan deskriptif dan studi kasus. Penelitian deskriptif 
bertujuan memberikan gambaran tentang sesuatu yang sedang berlangsung saat penelitian dilakukan. Penelitian dengan metode studi kasus, menghendaki suatu kajian yang rinci, mendalam dan menyeluruh atas objek tertentu yang biasanya relatif kecil selama kurun waktu tertentu.

Jenis data yang digunakan bersifat kualitatif dan kuantitatif. Data kualitatif berupa pernyataan responden dari wawancara yang menjabarkan visi, misi, strategi perusahaan, KPI dan peta strategi. Data kuantitatif berupa data yang digunakan dalam pengukuran kinerja. Sumber data yang digunakan untuk penelitian ini meliputi data primer (pihak internal dan eksternal perusahaan), kuesioner dan wawancara. dan data sekunder (studi literatur yang relevan dengan penelitian seperti buku, tesis, disertasi, data perusahaan dan data publikasi lainnya). Teknik pengambilan sampel informasi dilakukan sebagai berikut:

\section{Responden Kuesioner}

Pemilihan responden pada penyebaran kusioner penelitian ini terbagi dua kelompok, yaitu responden internal (karyawan) dan responden eksternal (pelanggan) perusahaan. Berdasarkan jumlah karyawan yang ada pada PT PDMA adalah 24 orang maka seluruh karyawan menjadi responden internal perusahaan, sedangkan untuk jumlah responden eksternal perusahaan dipilih konsumen perusahaan yang telah menjadi pelanggan tetap minimal tiga tahun, yaitu 17 pelanggan.

\section{Perancangan BSC}

Penilaian pada penentuan strategi BSC yang diambil yaitu dari interview yang lebih dalam (in depth interview) pada pimpinan sebagai pakar yang ada di PT PDMA. Para pakar tersebut ditentukan oleh perusahaan dimana mereka adalah para pengambil keputusan perusahaan yang sudah lama pada posisinya.

Teknik pengolahan dan analisis data dalam penelitian ini adalah 1) membobotkan tingkat kepentingan keempat perspektif BSC; 2) membobotkan tingkat kepentingan indikator kinerja kunci (KPI); 3) pembobotan dilakukan dengan menggunakan metode paired comparison atau perbandingan berpasangan, yaitu skala $1-5$. Selanjutnya mengalikan bobot dari masing-masing indikator kinerja kunci (KPI) dengan bobot perspektifnya. 4) mengukur kinerja KPI untuk menganalisis kinerja dari setiap ukuran kinerja kunci dalam indeks kinerja KPI.

Indeks kinerja tersebut menunjukan kinerja perusahaan yang diteliti seperti yang terlihat pada Tabel 1. Perancangan Balanced scorecard (BSC) PT PDMA diawali dengan penjabaran visi, misi dan strategi perusahaan. Selanjutnya dilakukan penetapan sasaran strategis PDMA berdasarkan wawancara dengan pihak manajemen dan menentukan key performance indicator (KPI), target serta inisiatif strategi dari setiap sasaran strategis tersebut. Langkah terakhir adalah membuat peta strategi.Melalui peta strategi (Strategy Map) sebuah perusahaan dapat mengkomunikasikan visi dan misi utama perusahaan kepada strategi pada masingmasing unit bisnis di perusahaan. Pembuatan peta strategi harus memperhatikan prinsip sebab-akibat, hasil dan faktor pendorong kinerja dan keterkaitan dengan masalah finansial (Kaplan dan Norton, 2000).

Tabel 1. Skala penilaian kinerja

\begin{tabular}{lll}
\hline $\begin{array}{c}\text { Skala penilaian } \\
\text { kinerja }(\%)\end{array}$ & \multicolumn{1}{c}{ Kategori } & \multicolumn{1}{c}{ Penjelasan } \\
\hline $1,00 \leq \mathrm{R}<14,30$ & Reassign $(\mathrm{R})$ & Perbaikan kembali \\
$14,30 \leq \mathrm{VP}<28,60$ & Very Poor $(\mathrm{VP})$ & Sangat tidak baik \\
$28,60 \leq \mathrm{P}<42,90$ & Poor $(\mathrm{P})$ & Tidak baik \\
$42,90 \leq \mathrm{A}<57,20$ & Average $(\mathrm{A})$ & Cukup baik \\
$57,20 \leq \mathrm{G}<71,50$ & Good $(\mathrm{G})$ & Baik \\
$71,50 \leq \mathrm{VG}<85,80$ & Very Good $(\mathrm{VG})$ & Sangat baik \\
$\mathrm{E} \geq 85,80$ & Excellent $(\mathrm{E})$ & Prima \\
\hline
\end{tabular}

Sumber: Lipe dan Salterio (2002)

Tahapan selanjutnya adalah mengukur kinerja aktual PT PDMA dengan kerangka BSC tersebut. Pengukuran kinerja perusahaan dilakukan dengan menyebarkan kuesioner kepada responden pada masing-masing perspektif strategis disesuaikan dengan kebutuhan informasi yang diperlukan dalam pengukuran. Hasil pengukuran kinerja kemudian dilakukan evaluasi kinerja dengan peta strategi yang menggambarkan hubungan sebab akibat antara sasaran strategis yang ada pada setiap perspektif. Kerangka pemikiran penelitian dapat dilihat pada Gambar 1. 


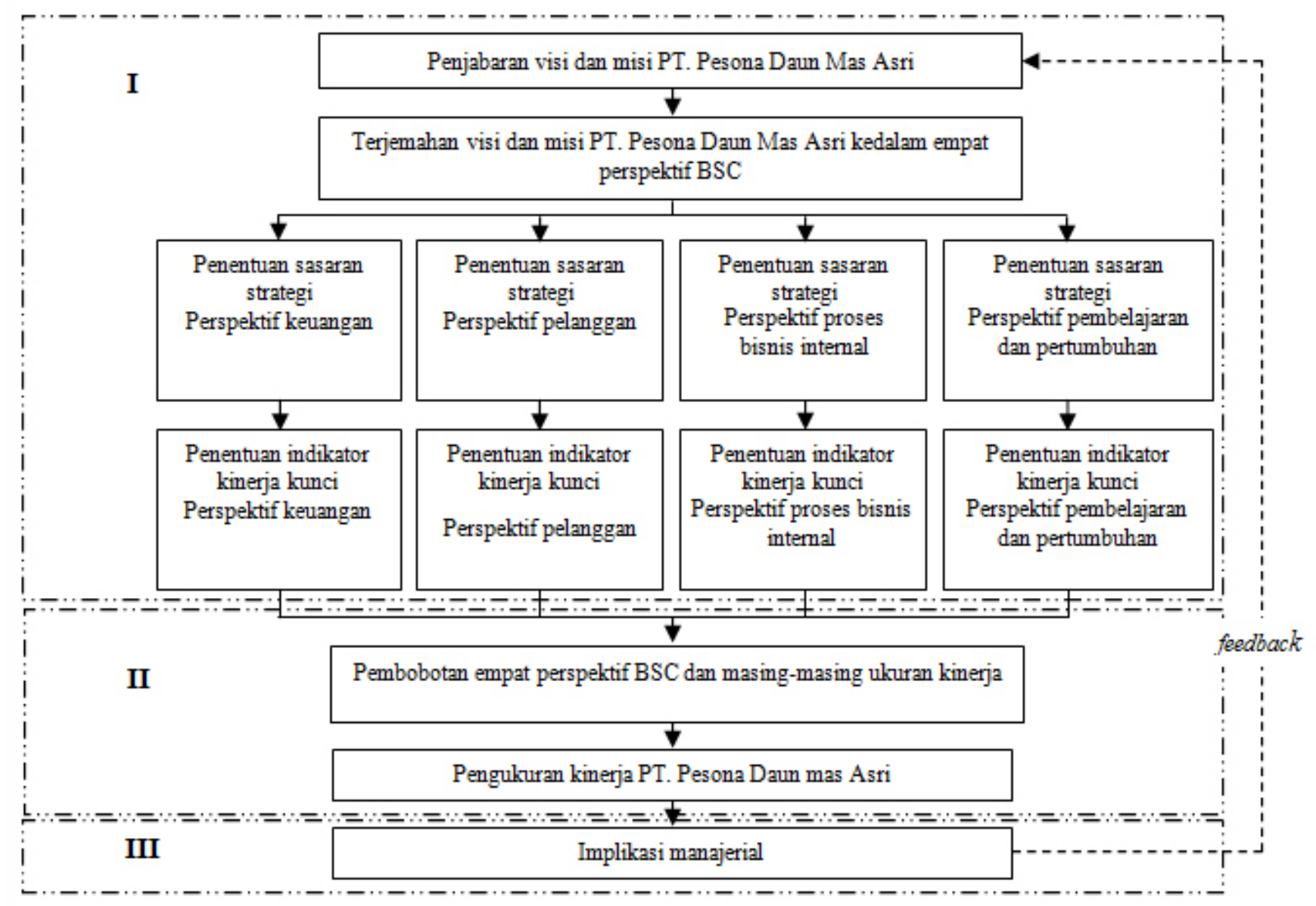

Gambar 1. Kerangka pemikiran penelitian

\section{HASIL}

\section{Perancangan Balanced Scorecard PT PDMA}

Perancangan BSC pada PT PDMA dilakukan dengan langkah-langkah sebagai berikut:

1. Penjabaran visi, misi dan strategi PT PDMA

Visi perusahaan adalah "Menjadi Perusahaan Tanaman Hias Potong Terbesar dan Terlengkap di Indonesia". Untuk mewujudkan visi tersebut maka perusahaan menetapkan misi "Meningkatkan kegiatan budi daya seoptimal mungkin serta meningkatkan penjualan dan keuntungan perusahaan setiap tahun dengan menyediakan berbagai jenis tanaman hias potong".

\section{Penetapan sasaran strategis PT PDMA}

Penetapan berdasarkan sasaran strategis perusahaan secara keseluruhan dan wawancara mendalam dengan pihak manajemendan disesuaikan dengan lingkungan baik internal maupun eksternal perusahaan.

3. Penentuan KPI, target dan inisiatif strategis dari setiap sasaran strategis.

\section{Penetapan Sasaran Strategis PT PDMA}

Penetapan sasaran strategis PT PDMA diperoleh dari hasil wawancara kepada pihak manajemen perusahaan dengan menggunakan Kuesioner dan dipadukan dengan studi literatur berdasarkan visi misi perusahaan. Hasil wawancara yang diitegrasikan dengan penelaahan visi misi perusahaan, diperoleh sasaran strategis perusahaan terbagi dalam empat perspektif BSC (keuangan, pelanggan, proses bisnis internal serta pertumbuhan dan pembelajaran). Pada (1) perspektif keuangan yaitu pertumbuhan modal, pertumbuhan penjualan/omzet dan efektivitas biaya pegawai; (2) perspektif pelanggan yaitu peningkatan kepuasan \& kepercayaan pelanggan, peningkatan pelayanan konsumen baru dan penanganan keluhan pelanggan; (3) perspektif proses bisnis internal yaitu peningkatan jenis produk, peningkatan kualitas budi daya pemeliharaan dan tenaga kerja budi daya optimal; (4) perspektif pembelajaran dan pertumbuhan yaitu peningkatankompetensi pemasaran, peningkatan kompetensi dan keterampilan pegawai, peningkatan motivasi pegawai dan peningkatan kepuasan pegawai. 


\section{Penetapan Key Performance Indicator (KPI), Target dan Inisiatif Strategi}

Penetapan KPI disusun berdasarkan wawancara kepada pakar yang disusun terdiri dari ukuran hasil (lag indicator) dan ukuran pemicu (lead indicator). KPI pada (1) perspektif keuangan yaitu laju pertumbuhan modal, laju pertumbuhan penjualan/omzet dan persentase biaya pegawai; (2) perspektif pelanggan, yaitu persepsi kepuasan pelanggan, jumlah pelanggan baru dan jumlah pelanggan hilang; (3) perspektif proses bisnis internal, yaitu jenis produk/tanaman baru, persentase tanaman sehat dan tingkat absen pegawai;
(4) perspektif pembelajaran dan pertumbuhan, yaitu mengikuti pameran, tingkat kompetensi pegawai, tingkatmotivasi pegawai dan tingkat kepuasan pegawai. Selanjutnya, ditetapkan target untuk setiap KPI. Penentuan target untuk KPI dilakukan berdasarkan diskusi dan wawancara dengan pihak perusahaan dengan mempertimbangkan pencapaian dan pengalaman perusahaan di tahun-tahun sebelumnya. Target yang ditetapkan terdiri atas target yang bersifat positif dan negatif. Selanjutnya, ditetapkan pula inisiatif strategi dari masing-masing KPI tersebut. Rancangan BSC PT. PDMA selengkapnya pada Tabel 2.

Tabel 2. Rancangan balanced scorecard PT PDMA

\begin{tabular}{|c|c|c|c|c|c|}
\hline Sasaran strategis & Indikator hasil & Indikator pemicu & Target & Satuan target & Inisiatif strategis \\
\hline \multicolumn{6}{|l|}{ Keuangan } \\
\hline Pertumbuhan modal & $\begin{array}{l}\text { Laju pertumbuhan } \\
\text { modal }\end{array}$ & $\begin{array}{l}\text { Keuntungan } \\
\text { bersih }\end{array}$ & $\geq 20$ & Persen & \\
\hline Pertumbuhan penjualan/omzet & $\begin{array}{l}\text { Laju pertumbuhan } \\
\text { penjualan/omzet }\end{array}$ & Penjualan/omzet & $\geq 20$ & Persen & \\
\hline Efektivitas biaya pegawai & $\begin{array}{l}\text { Persentase biaya } \\
\text { pegawai }\end{array}$ & $\begin{array}{l}\text { Total biaya upah } \\
\text { pegawai }\end{array}$ & $\leq 30$ & Persen & \\
\hline \multicolumn{6}{|l|}{ Pelanggan } \\
\hline $\begin{array}{l}\text { Peningkatan kepuasan dan } \\
\text { kepercayaan pelanggan }\end{array}$ & $\begin{array}{l}\text { Persepsi kepuasan } \\
\text { pelanggan }\end{array}$ & Bauran pemasaran & $\geq 75$ & Persen & $\begin{array}{l}\text { Fokus pada } \\
\text { bauran pemasaran }\end{array}$ \\
\hline $\begin{array}{l}\text { Peningkatan pelayanan } \\
\text { konsumen baru }\end{array}$ & Pelanggan baru & $\begin{array}{l}\text { Bauran pemasaran } \\
\text { konsumen baru }\end{array}$ & $\geq 6$ & $\begin{array}{l}\text { Pelanggan } \\
\text { baru }\end{array}$ & Promosi \\
\hline $\begin{array}{l}\text { Penanganan keluhan } \\
\text { pelanggan }\end{array}$ & Pelanggan hilang & $\begin{array}{l}\text { Pelayanan solusi } \\
\text { komplain/keluhan }\end{array}$ & $\leq 0$ & $\begin{array}{l}\text { Pelanggan } \\
\text { hilang }\end{array}$ & $\begin{array}{l}\text { Kualitas dan } \\
\text { kuantitas }\end{array}$ \\
\hline \multicolumn{6}{|l|}{ Proses bisnis internal } \\
\hline Peningkatan jenis produk & Jenis produk baru & $\begin{array}{l}\text { Budi daya produk } \\
\text { baru }\end{array}$ & $\geq 4$ & $\begin{array}{l}\text { Jumlah } \\
\text { tanaman }\end{array}$ & Informasi \\
\hline \multicolumn{6}{|l|}{ Uji coba } \\
\hline $\begin{array}{l}\text { Peningkatan kualitas budi daya } \\
\text { pemeliharaan }\end{array}$ & $\begin{array}{l}\text { Persentase } \\
\text { tanaman sehat }\end{array}$ & $\begin{array}{l}\text { Pengendalian } \\
\text { hama penyakit }\end{array}$ & $\geq 100$ & Persen & $\begin{array}{l}\text { Informasi } \\
\text { pengendalian } \\
\text { hama penyakit }\end{array}$ \\
\hline $\begin{array}{l}\text { Tenaga kerja budi daya } \\
\text { optimal }\end{array}$ & $\begin{array}{l}\text { Tingkat absen } \\
\text { pegawai }\end{array}$ & $\begin{array}{l}\text { Kehadiran } \\
\text { pegawai }\end{array}$ & $\leq 8$ & Persen & $\begin{array}{l}\text { Motivasi dan } \\
\text { kepuasan pegawai }\end{array}$ \\
\hline \multicolumn{6}{|l|}{$\begin{array}{l}\text { Pembelajaran dan } \\
\text { pertumbuhan }\end{array}$} \\
\hline $\begin{array}{l}\text { Peningkatan kompetensi } \\
\text { pemasaran }\end{array}$ & $\begin{array}{l}\text { Mengikuti } \\
\text { pameran }\end{array}$ & $\begin{array}{l}\text { Kompetensi } \\
\text { pemasaran }\end{array}$ & $\geq 4$ & $\begin{array}{l}\text { Jumlah } \\
\text { pameran }\end{array}$ & $\begin{array}{l}\text { Informasi } \\
\text { pameran dan } \\
\text { asosiasi }\end{array}$ \\
\hline $\begin{array}{l}\text { Peningkatan kompetensi dan } \\
\text { keterampilan pegawai }\end{array}$ & $\begin{array}{l}\text { Tingkat } \\
\text { kompetensi } \\
\text { pegawai }\end{array}$ & $\begin{array}{l}\text { Kompetensi } \\
\text { pegawai }\end{array}$ & $\geq 85$ & Persen & $\begin{array}{l}\text { Melakukan } \\
\text { pelatihan dan } \\
\text { pengawasan }\end{array}$ \\
\hline Peningkatan motivasi pegawai & $\begin{array}{l}\text { Tingkat motivasi } \\
\text { pegawai }\end{array}$ & Motivasi pegawai & $\geq 85$ & Persen & $\begin{array}{l}\text { Penghargaan } \\
\text { pegawai }\end{array}$ \\
\hline Peningkatan kepuasan pegawai & $\begin{array}{l}\text { Tingkat kepuasan } \\
\text { pegawai }\end{array}$ & Kepuasan pegawai & $\geq 85$ & Persen & $\begin{array}{l}\text { Kebutuhan } \\
\text { pegawai }\end{array}$ \\
\hline
\end{tabular}




\section{Pengukuran Kinerja PT PDMA dengan BSC}

Rancangan BSC yang telah terbentuk dapat digunakan untuk mengukur dan mengevaluasi kinerja PDMA. Pengukuran kinerja perusahaan secara keseluruhan dilakukan dengan menggunakan Microsoft Excel. Kinerja PDMA secara keseluruhan dapat dihitung dengan mengalikan antara komponen-komponen penyusunnya, yaitu bobot setiap perspektif dan KPI serta indeks kinerja. Indeks kinerja KPI dikelompokan berdasarkan rentang nilai kinerja.

\section{Pembobotan Perspektif BSC dan KPI}

Pembobotan dilakukan dengan mewawancarai pihak manajemen perusahaan, pembobotan bertujuan agar dapatdiketahuiseberapabesarpengaruhsetiapperspektif terhadap kinerja perusahaan secara keseluruhan. Hasil pembobotan pihak manajemen diolah menggunakan metode paired comparison (perbandinganberpasangan). Pembobotan menghasilkan nilai rata-rata seperti yang terlihat pada Tabel 3. Hasil pembobotan dapat diketahui bahwa perspektif yang memiliki bobot tertinggi adalah perspektif keuangan, yaitu sebesar $38,89 \%$, perspektif pelanggan sebesar $30,56 \%$, perspektif pertumbuhan dan pembelajaran sebesar $22,22 \%$ dan perspektif proses bisnis internal sebesar 8,33\%.

Pembobotan yang dilakukan pada masing-masing KPI menunjukan bahwa pertumbuhan penjualan/ omzet memiliki pengaruh terbesar terhadap kinerja perusahaan secara keseluruhan yaitu sebesar 21,61\% diikuti efektivitas biaya pegawai sebesar $12,96 \%$.

Dari hasil pembobotan tersebut perusahaan dapat menentukan prioritas utama perspektif atau KPI yang perlu dikaji jika perusahaan bermasalah atau memiliki kinerja rendah. BSC bermanfaat bagi perusahaan untuk mengidentifikasi permasalahan kinerja secara lebih efisien. Perspektif dan KPI yang perlu menjadi prioritas utama adalah perspektif dan KPI yang memiliki bobot pengaruh terbesar terhadap kinerja perusahaan.

\section{Pengukuran Pencapaian Target KPI}

Pada perspektif keuangan PT PDMA meliputi: (1) pertumbuhan modal mencapai target sebesar $96,30 \%$; (2) pertumbuhan penjualan mencapai target sebesar $49,80 \%$; (3) persentase biaya pegawai mencapai target sebesar $85,23 \%$. Pencapaian target KPI terendah pada perspektif keuangan adalah pertumbuhan penjualan. Pihak manajemen perlu mengkaji hal-hal yang mengakibatkan pencapaian target pertumbuhan penjualan yang rendah, dengan menggunakan peta strategi BSC sebagai bahan referensi melakukan evaluasi.

Pada perspektif pelanggan PT PDMA terdiri atas: (1) kepuasan pelanggan mencapai terget sebesar $95,20 \%$; (2) pelayanan konsumen baru mencapai target sebesar $83,33 \%$; (3) penanganan keluhan pelanggan mencapai target sebesar 100,00\%. Secara umum kinerja PT PDMA menurut perspektif pelanggan sudah baik. Perusahaan mampu memberikan kepuasan yang sesuai dengan yang diharapkan oleh para pelanggan, namun pihak manajemen harus tetap menjaga loyalitas pelanggan tersebut karena tingkat persaingan yang umumnya semakin tinggi.

Pada perspektif proses bisnis internal PT PDMA terdiri atas: (1) jenis tanaman baru mencapai target sebesar $75,00 \%$; (2) pengendalian hama penyakit mencapai target sebesar $80,00 \%$; (3) tenaga kerja budi daya optimal mencapai target sebesar $101,50 \%$. Pencapaian target KPI pada perspektif proses bisnis internal sudah baik, perusahaan mampu menjaga faktor kunci pada proses internal produksi. Untuk tetapmempertahankan dan meningkatkan kinerja perusahaan secara keseluruhan, manajemen sebaiknya meningkatkan kegiatan yang mendukung penambahan jenis tanaman baru, selain memiliki bobot terbesar pada perspektif ini, pelanggan akan lebih tertarik dengan semakin banyaknya pilihan produk.

Pada perspektif pembelajaran dan pertumbuhan PT PDMA meliputi: (1) kegiatan pemasaran mencapai target sebesar $50,00 \%$; (2) kompetensi pegawai mencapai target sebesar $83,01 \%$; (3) motivasi pegawai mencapai target sebesar $88,84 \%$; (4) kepuasan pegawai mencapai target sebesar $89,54 \%$. Kegiatan pemasaran adalah KPI yang memiliki pencapaian target terendah, perusahaan harus melakukan kegiatan yang dapat mendorong meningkatnya kinerja KPI ini. Sebab kegiatan pemasaran memiliki nilai bobot terbesar yang Memengaruhi kinerja perusahaan secara kesuluruhan pada perspektif pembelajaran dan pertumbuhan, selain itu kondisi pasar yang semakin bersaing dengan adanya ancaman dari produsen baru tanaman hias potong. 


\section{Hasil Penilaian Indeks Kinerja PT PDMA}

Indeks kinerja PT PDMA adalah penilaian kinerja usaha yang menggambarkan posisi keberhasilan strategi perusahaan tersebut dalam mencapain sasarannya. Hasil perhitungan didapatkan indeks kinerja PT PDMA secara keseluruhan yang mencapai angka 78,04\% sehingga termasuk kriteria kinerja very good atau sangat baik. Untuk mempertahankan dan meningkatkan pencapaian kinerja PT PDMA secara keseluruhan, pihak manajemen harus tetap melakukan perbaikan kinerja. Tabel 3 menunjukan hasil pengukuran indeks kinerja PT PDMA.

Tabel 3. Hasil pengukuran indeks kinerja PT PDMA

\begin{tabular}{|c|c|c|c|c|c|c|c|}
\hline Sasaran strategis & Ukuran strategis & $\begin{array}{l}\text { Target } \\
\text { (a) }\end{array}$ & $\begin{array}{l}\text { Realisasi } \\
\text { (b) }\end{array}$ & $\begin{array}{c}\text { Satuan } \\
\text { Target \& } \\
\text { Realisasi }\end{array}$ & $\begin{array}{c}\text { Pencapaian } \\
\text { Target } \\
(\mathrm{c}=\mathrm{b} / \mathrm{a}) \\
(\%)\end{array}$ & $\begin{array}{l}\text { Bobot } \\
\text { (d) } \\
(\%)\end{array}$ & $\begin{array}{c}\text { Skor } \\
(\mathrm{e}=\mathrm{c} \mathrm{x} \mathrm{d}) \\
(\%)\end{array}$ \\
\hline \multicolumn{8}{|l|}{ Finansial $(38,89 \%)$} \\
\hline $\begin{array}{l}\text { 1. Pertumbuhan modal } \\
\text { 2. Pertumbuhan }\end{array}$ & $\begin{array}{l}\text { 1. Laju pertumbuhan } \\
\text { modal }(11,11 \%)\end{array}$ & $\geq 20$ & 19,26 & Persen & 96,30 & 4,32 & 4,16 \\
\hline penjualan/omzet & 2. Laju pertumbuhan & $\geq 20$ & 9,96 & Persen & 49,80 & 21,61 & 10,76 \\
\hline 3. Efektivitas biaya & penjualan $(55,56 \%)$ & & & & & & \\
\hline pegawai & $\begin{array}{l}\text { 3. Persentase biaya } \\
\text { pegawai }(33,33 \%)\end{array}$ & $\leq 30$ & 34,43 & Persen & 85,23 & 12,96 & 11,05 \\
\hline & Total $=100 \%$ & & & & 66,78 & 38,89 & 25,97 \\
\hline \multicolumn{8}{|l|}{ Customer $(30,56 \%)$} \\
\hline $\begin{array}{l}\text { 1. Peningkatan } \\
\text { kepuasan \& }\end{array}$ & $\begin{array}{l}\text { 1. Persepsi kepuasan } \\
\text { pelanggan }(38,89 \%)\end{array}$ & $\geq 75$ & 71,40 & Persen & 95,20 & 11,88 & 11,31 \\
\hline $\begin{array}{l}\text { kepercayaan } \\
\text { pelanggan }\end{array}$ & $\begin{array}{l}\text { 2. Pelanggan baru } \\
(22,22 \%)\end{array}$ & $\geq 6$ & 5 & $\begin{array}{l}\text { Pelanggan } \\
\text { Baru }\end{array}$ & 83,33 & 6,80 & 5,67 \\
\hline $\begin{array}{l}\text { 2. Peningkatan } \\
\text { pelayanan konsumen } \\
\text { baru }\end{array}$ & $\begin{array}{l}\text { 3. Pelanggan hilang } \\
(38,89 \%)\end{array}$ & $\leq 0$ & 0 & $\begin{array}{l}\text { Pelanggan } \\
\text { Hilang }\end{array}$ & 100,00 & 11,88 & 11,88 \\
\hline \multicolumn{8}{|l|}{$\begin{array}{l}\text { 3. Penanganan keluhan } \\
\text { pelanggan }\end{array}$} \\
\hline & Total $=100 \%$ & & & & 94,44 & 30,56 & 28,86 \\
\hline \multicolumn{8}{|l|}{ Internal Business } \\
\hline $\begin{array}{l}\text { 1. Peningkatan jenis } \\
\text { produk }\end{array}$ & $\begin{array}{l}\text { 1. Jenis produk/tanaman } \\
\text { baru }(44,44 \%)\end{array}$ & $\geq 4$ & 3 & $\begin{array}{l}\text { Produk } \\
\text { Baru }\end{array}$ & 75,00 & 3,70 & 2,78 \\
\hline $\begin{array}{l}\text { 2. Peningkatan } \\
\text { kualitas budi daya }\end{array}$ & $\begin{array}{l}\text { 2. Persentase tanaman } \\
\text { sehat }(38,89 \%)\end{array}$ & $=100$ & 80 & Persen & 80,00 & 3,24 & 2,59 \\
\hline \multirow{2}{*}{$\begin{array}{l}\text { 3. Tenaga kerja budi } \\
\text { daya optimal }\end{array}$} & $\begin{array}{l}\text { 3. Tingkat absen } \\
\text { pegawai }(16,67 \%)\end{array}$ & $\leq 8$ & 7,88 & Persen & 101,50 & 1,39 & 1,41 \\
\hline & Total $=100 \%$ & & & & 81,39 & 8,33 & 6,78 \\
\hline \multicolumn{8}{|l|}{$\begin{array}{l}\text { Learning \& Growth } \\
(22,22 \%)\end{array}$} \\
\hline $\begin{array}{l}\text { 1. Peningkatan } \\
\text { kompetensi }\end{array}$ & $\begin{array}{l}\text { 1. Mengikuti pameran } \\
(36,11 \%)\end{array}$ & $\geq 4$ & 2 & $\begin{array}{l}\text { Jumlah } \\
\text { Pameran }\end{array}$ & 50,00 & 8,02 & 4,01 \\
\hline $\begin{array}{l}\text { pemasaran } \\
\text { 2. Peningkatan }\end{array}$ & $\begin{array}{l}\text { 2. Tingkat kompetensi } \\
\text { pegawai }(16,67 \%)\end{array}$ & $\geq 85$ & 70,56 & Persen & 83,01 & 3,70 & 3,07 \\
\hline $\begin{array}{l}\text { kompetensi \& } \\
\text { keterampilan pegawai }\end{array}$ & $\begin{array}{l}\text { 3. Tingkat motivasi } \\
\text { pegawai }(30,56 \%)\end{array}$ & $\geq 85$ & 75,51 & Persen & 88,84 & 6,80 & 6,04 \\
\hline $\begin{array}{l}\text { 3. Peningkatan motivasi } \\
\text { pegawai }\end{array}$ & $\begin{array}{l}\text { 4. Tingkat kepuasan } \\
\text { pegawai }(16,67 \%)\end{array}$ & $\geq 85$ & 76,11 & Persen & 89,54 & 3,70 & 3,31 \\
\hline \multicolumn{8}{|c|}{ 4. Peningkatan } \\
\hline & Total $=100 \%$ & & & & 73,94 & 22,22 & 16,43 \\
\hline Total $=100 \%$ & & & & & & Very good & 78,04 \\
\hline
\end{tabular}




\section{Implikasi Manajerial}

Hasil evaluasi kinerja PT PDMA, manajemen disarankan meningkatkan kinerja KPI yang dinilai belum optimal. Tabel 4 memperlihatkan implikasi manajerial bagi manajemen PT PDMA. KPI yang dinilai belum optimal tersebut adalah tingkat pertumbuhan penjualan (average) dan kegiatan pemasaran (average). Apabila manajemen tidak segera memperbaiki kinerja KPI tersebut maka akan menghambat tercapainya visi dan misi PT PDMA secara keseluruhan. Hasil pembobotan tingkat kepentingan perspektif BSC dapat diketahui bahwa perspektif keuangan dan perspektif pelanggan dinilai paling penting oleh manajemen di lingkungan PT PDMA dibandingkan perspektiflainnya. Ditinjau dari tingkat kepentingannya, manajemen menilai bahwa KPI pertumbuhan penjualan dinilai paling penting sebab penjualan menjadi salah satu indikator utama perusahaaan untuk keberlangsungan dan perkembangan perusahaan yang pada akhirnya mampu meningkatkan kinerja perusahaan secara keseluruhan.

Perolehan indeks kinerja tingkat pertumbuhan penjualan mencapai $49,80 \%$ dan termasuk kriteria cukup baik (average) dan bobot tingkat kepentingannya paling tinggi dibanding KPI lainnya, yaitu mencapai 21,61\% sehingga berpotensi meraih kinerja yang tidak baik apabila tidak dikelola dengan benar oleh manajemen. Manajemen perlu mempertimbangkan pemenuhan tingkat pertumbuhan penjualan yang belum memenuhi target. Untuk lebih jelasnya hasil pengukuran kinerja perusahaan dapat dilihat pada Tabel 3.

\section{KESIMPULAN DAN SARAN}

\section{Kesimpulan}

Proses perancangan BSC menghasilkan sasaran strategis (KPI) pada setiap perspektif. Setiap sasaran strategis memiliki hubungan sebab akibat yang ditunjukkan oleh peta strategi. Sasaran strategis yang ingin dicapai PT PDMA pada perspektif keuangan adalah pertumbuhan modal, pertumbuhan penjualan/ omzet dan efektivitas biaya pegawai. Untuk mencapai sasaran strategis pada perspektif keuangan perusahaan dapat mencapainya melalui pencapaian sasaran strategis pada perspektif pelanggan, yaitu peningkatan kepuasan dan kepercayaan pelanggan, peningkatan jumlah pelanggan dan penurunan komplain/keluhan pelanggan. Tercapainya sasaran strategis perspektif pelanggan akan diwujudkan melalui sasaran-sasaran strategis proses bisnis internal, yaitu peningkatan jenis produk, peningkatan kualitas budi daya pemeliharaan dan penurunan absen pegawai. Semua sasaran strategis tersebut di atas dapat diwujudkan melalui tercapainya sasaran strategis dalam perspektif pembelajaran dan pertumbuhan, yaitu peningkatan kompetensi pemasaran, peningkatan kompetensi dan keterampilan pegawai, peningkatan motivasi pegawai dan peningkatan kepuasan pegawai. Secara keseluruhan hasil pencapaian kinerja PT PDMA sebesar 78,04\% atau masuk dalam kategori very good.Pencapaian tersebut dianggap sudah sangat baik bagi pihak manajemen, namun untuk mempertahankan maupun meningkatkan kinerja yang lebih baik lagi perusahaan harus selalu melakukan perbaikan secara terus menerus. Untuk meningkatkan kinerja PT PDMA, perusahaan sebaiknya fokus pada sasaran strategis (KPI) yang memiliki pencapaian kinerja paling rendah yaitu tingkat pertumbuhan penjualan dan kegiatan pemasaran.

Tabel 4. Implikasi manajerial PT PDMA

\begin{tabular}{lll}
\hline \multicolumn{1}{c}{ Masalah } & \multicolumn{1}{c}{ Solusi } & \multicolumn{1}{c}{ Pelaksana } \\
\hline Tidak tercapainya sasaran strategis & Meningkatkan volume penjualan & Manajer produksi pemasaran \\
pertumbuhan penjualan/omzet yang & PDMA tahun kedepan. Hal tersebut & \\
ditandai dengan pencapaian kinerja & dilakukan dengan kerjasama yang baik & \\
KPI tingkat pertumbuhan penjualan & dan terintegrasi antara bagian produksi & \\
PDMA dengan kriteria cukup baik & dan pemasaran. & Manajer pemasaran \\
(average). & & \\
Tidak tercapainya sasaran strategis & Meningkatkan kegiatan promosi & \\
peningkatan kompetensi pemasaran & dan pemasaran PDMA baik dengan & \\
yang ditandai dengan pencapaian & mengikuti pameran maupun dengan & \\
kinerja KPI kegiatan pemasaran & sistem mendatangi calon pelanggan & \\
PDMA dengan kriteria cukup baik & baru seperti florist, dekorator dan & \\
(average). & perangkai. & \\
\hline
\end{tabular}




\section{Saran}

Tingkat persaingan usaha tanaman hias potong yang semakin tinggi dengan kondisi pasar yang selalu berubah menyebabkan PT PDMA harus mampu menerapkan sistem penilaian kinerja yang dapat menggambarkan kondisi dan potensi yang dimiliki perusahaan. Selanjutnya, PT PDMA sebaiknya menggunakan metode BSC sebagai standar penilaian kinerja yang baku, karena mampu melakukan penilaian kinerja secara menyeluruh dan komprehensif. Selain itu upaya mencapai tujuan organisasi di masa depan dapat dilakukan dengan mengimplementasikan BSC (Moghadam et al. 2012).

Perusahaan tanaman hias potong PPT PDMA sebaiknya melakukan pencatatan yang lebih baik tentang kinerja serta permasalahan dan solusi pada masing-masing bagian sehingga manfaatnya akan memudahkan dalam proses penilaian kinerja perusahaan secara keseluruhan, sebab dalam pengukuran kinerja perusahaan, informasi data dan kinerja perusahaan sebelumnya sangat penting untuk mengetahui posisi perusahaan saat ini serta dibutuhkan untuk perancangan rencana perusahaan di masa yang akan datang. Hasil penelitian ini dapat membantu penelitian selanjutnya dalam mengukur kinerja perusahaan sejenis serta dalam merencanakan strategi perusahaan dalam menghadapi pasar yang dinamis.

\section{DAFTAR PUSTAKA}

Alhyari S, Alazab M, Venkatraman S, Alazab A. 2013. Performance evaluation of e-government services using balanced scorecard: An Empirical Study in Jordan. An International Journal 20(4):512-536.

Alsyouf I. 2006. Measuring maintenance performance using a balanced scorecard approach. Journal of Quality Maintenance Engineering 12(2): 133149.

Al-Zwyalif IM. 2012. The possibility of implementing balanced scorecard in Jordanian Private Universities. International Business Research. 5(11):113-120.

Anggraini RI, Hubeis AV, Tampubolon R. 2016. Evaluasi kinerja unit bisnis asphalt mixing plant PT Prayoga Pertambangan dan Energi. Jurnal Aplikasi Bisnis dan Manajemen 2 (2): 127-137.
Ardekani SS, Sharifabadi AM, Jalaly M, Zarch ME. 2013. Comprehensive performance evaluation using FAHP-FVIKOR Approach Based on Balanced Scorecard (BSC): A Case of Yazd's Ceramic and Tile Industry. Iranian Journal of Management Studies 6(2):81-104.

Chavan M. 2009. The balanced scorcard: a new challenge. Journal of Management Development 28(5):393-406.

Christina NPY, Sudana IP. 2013. Penilaian kinerja pada pt adhi karya dengan pendekatan balanced scorecard. E-Jurnal Akuntansi Universitas Udayana 5(3):516-529.

Ghalayini AM, Noble JS, Crowe TJ. 1997. An integrated dynamic performance measurement system for improving manufacturing competitiveness. International Journal of Production Economics 48(3):207-225.

Gibson JL, Ivancevich JM, Donnelly JH, Konopaske R. 2009. Organizations: behavior, structure and processess. New York: McGraw-Hill.

Humphreys KA, Trotman KT. 2011. The balanced scorecard : the effect of strategy information on performance evaluation judgements. Journal of Management Accounting Research 23: 21-98.

Kaplan RS, Norton DP. 1996. The Balanced Scorecard. Boston: Harvard Business School Press.

Lipe, M. G. dan S. Salterio. 2002. A Note on the judgmental effects of the balanced scorecard's information organization. Accounting, Organization and Society 27: 531-540.

Maula K, Ghozali K. 2012. Evaluasi kinerja IT pada PT XYZ menggunakan IT balanced scorecard. Jurnal Teknik POMITS 1(1):1-6.

Moghadam SK, Masoud TL, Anis I, Saghi L. 2012. Reviewing the role of implementation of the Balanced scorecard in assesing the performance of public sector. Interdisciplinary Journal of Contemporary Research in Busines 4(7): 890896.

Neely AD, Adams CA. 2000. Perspectives on Performances: The Performance Prism, Centre for Business Performance. Cranfield: Cranfield School of Management.

Ratih MK, Anas MF, Achmad C. 2012. Daya saing PT Benar Flora Utama berdasarkan aktivitas rantai nilai florikultura. Jurnal Manajemen \& Aggribisnis 9(3): 146-153.

Suryani D, Syarief R, Suroso AI. 2014. Perancangan balanced scorecard untuk pengembangan 
strategi di Seameo Biotrop. Jurnal Manajemen dan Agribisnis 11(1):33-40.

Wibowo. 2007. Manajemen Kinerja. Jakarta: Rajawali Pers.
Yu L, Li C. 2013. Applied research on the Balanced scorecard in the performance evaluation of banks of village and town. Management and Engineering Journal 10:160-164. 